\title{
Unexpected Subtilisin-Catalyzed Hydrolysis of a Sulfinamide Bond in Preference to a Carboxamide Bond in $\mathrm{N}$-Acyl Sulfinamides
}

\author{
Paul F. Mugford, Vladimir P. Magloire and Romas J. Kazlauskas* \\ Department of Chemistry, McGill University, 801 Sherbrooke St. W., Montréal, Québec H3A \\ 2K6, Canada \\ Department of Biochemistry, Molecular Biology \& Biophysics \& The Biotechnology Institute, \\ University of Minnesota, 1479 Gortner Avenue, Saint Paul, MN 55108, USA
}

\section{Supporting Information}

Synthesis of $N$-acyl-p-toluenesulfinamides. $N$-acyl-p-toluenesulfinamides ${ }^{1}$ were prepared by acylation of the corresponding $p$-toluenesulfinamide with 2 equivalents of $n$-butyl lithium and addition of the appropriate anhydride ${ }^{2}$ to give the $N$-acyl sulfinamide, Scheme S-1.

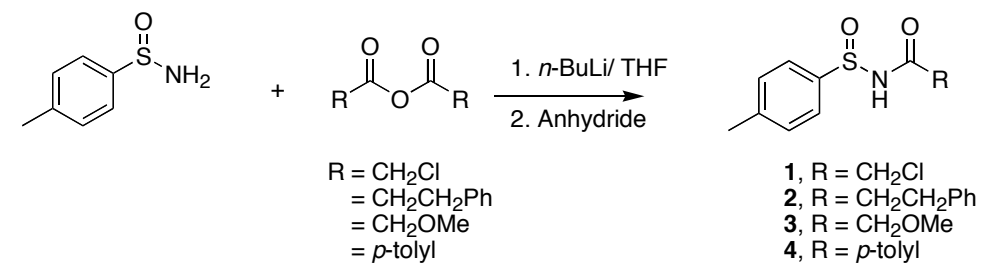

Scheme S-1: Synthesis of $N$-acyl-p-toluenesulfinamides.

$\mathrm{N}$-Chloroacetyl-p-toluenesulfinamide, 1. White solid, $1.22 \mathrm{~g}(41 \%), \mathrm{mp} 115-117^{\circ} \mathrm{C}$ (lit 119-

$\left.121{ }^{\circ} \mathrm{C}^{3}\right) ;{ }^{1} \mathrm{H}$ NMR $\left(300 \mathrm{MHz}, \mathrm{CDCl}_{3} \delta\right): 2.43$ (s, 3H), $4.29(\mathrm{~s}, 2 \mathrm{H}), 7.31(\mathrm{~d}, J=8.1,2 \mathrm{H}), 7.63(\mathrm{~d}$, $J=8.1,2 \mathrm{H}) ;{ }^{13} \mathrm{C} \mathrm{NMR}\left(\mathrm{CDCl}_{3}, \delta\right): 21.8,42.5,124.8,130.6,139.9,143.5,167.2$, HR-EIMS $m / z$ :

$\mathrm{M}+\mathrm{Na}^{+}$calcd for $\mathrm{C}_{9} \mathrm{H}_{10} \mathrm{NO}_{2} \mathrm{SNa} 254.0023$, found 254.0013.

$\boldsymbol{N}$-Dihydrocinnamoyl-p-toluenesulfinamide, 2. White solid, $2.31 \mathrm{~g}(63 \%)$, mp $97-99{ }^{\circ} \mathrm{C}$ (lit.

94-96 ${ }^{\circ} \mathrm{C}^{\mathrm{l}}$ ); ${ }^{1} \mathrm{H}$ NMR (300 MHz, $\mathrm{CDCl}_{3} \delta$ ): 2.39 (s, 3H), 2.65 (m, 2H), $2.96(\mathrm{t}, J=7.5,2 \mathrm{H}), 7.12-$

$7.29(\mathrm{~m}, 7 \mathrm{H}), 7.35(\mathrm{~d}, J=8.4,2 \mathrm{H}), 8.39(\mathrm{~s}, 1 \mathrm{H}) ;{ }^{13} \mathrm{C} \mathrm{NMR}\left(\mathrm{CDCl}_{3}, \delta\right): 21.5,30.9,37.7,124.8$,

126.5, 128.5, 128.7, 130.1, 140.1, 140.2, 142.6, 173.3, HR-EIMS m/z: $\mathrm{M}+\mathrm{Na}^{+}$calcd for

$\mathrm{C}_{16} \mathrm{H}_{17} \mathrm{NO}_{2} \mathrm{SNa} 310.0883$, found 310.0881 .

$N$-Methoxyacetyl-p-toluenesulfinamide, 3. White solid, $520 \mathrm{mg}$ (21\%), mp $62-64{ }^{\circ} \mathrm{C}$ (lit. $57-59$

$\left.{ }^{\circ} \mathrm{C}^{2}\right) ;{ }^{1} \mathrm{H}$ NMR (300 MHz, $\mathrm{CDCl}_{3} \delta$ ): $\delta 2.44$ (s, 3H), 3.37 (s, 3H), 4.00 (s, 2H), 7.39 (d, J = 8.4,

$2 \mathrm{H}), 7.63(\mathrm{~d}, J=8.42 \mathrm{H}), 8.328(\mathrm{~s}, 1 \mathrm{H}){ }^{13} \mathrm{C} \mathrm{NMR}\left(\mathrm{CDCl}_{3}, \delta\right): 21.6,59.3,71.7,124.7,130.2$,

140.4, 142.9, 170.6, HR-EIMS $m / z: \mathrm{M}+\mathrm{Na}^{+}$calcd for $\mathrm{C}_{10} \mathrm{H}_{13} \mathrm{NO}_{2} \mathrm{SNa} 250.0519$, found 250.0504 . 
$N$-p-toluoyl -p-toluenesulfinamide, 4. White solid, $1.50 \mathrm{~g}(43 \%), \mathrm{mp} 124-125{ }^{\circ} \mathrm{C},{ }^{1} \mathrm{H}$ NMR $\left(300 \mathrm{MHz}, \mathrm{CDCl}_{3} \delta\right): 2.38$ (s, 3H), 2.40 (s, 3H), 7.21 (d, J=8.4, 2H), $7.29(\mathrm{~m}, J=8.4,2 \mathrm{H}), 7.60$ $(\mathrm{d}, J=8.4,2 \mathrm{H}), 7.72(\mathrm{~m}, J=8.4,2 \mathrm{H}), 8.93(\mathrm{~s}, 1 \mathrm{H}){ }^{13} \mathrm{C} \mathrm{NMR}\left(\mathrm{CDCl}_{3}, \delta\right): 21.5,21.7,125.0$, 128.2, 128.9, 129.5, 130.1, 140.7, 143.6, 144.1, 167.5, HR-EIMS m/z: M+Na calcd for $\mathrm{C}_{15} \mathrm{H}_{15} \mathrm{NO}_{2} \mathrm{SNa} 296.0726$, found 296.0734.

Subtilisin Carlsberg. Three commercial samples of subtilisin Carlsberg were used: Fluka 82518 (11.7 U/mg), Sigma P5380 (11.4 U/mg), Sigma P8038 (9.2 U/mg), activity from the manufacturer (Sigma-Aldrich, St. Louis, MO). Electrospray ionization mass spectrometry (Q Star, Applied Biosystems, Foster City, CA) confirmed that the commercial samples were indeed subtilisin Carlsberg. The phenylmethylsulfonyl fluoride-inhibited (PMSF) enzyme revealed a molecular weight of Fluka 82518: 27440 Da, Sigma P8038: 27441 Da, Sigma P5380: 27443 Da. This agrees with the predicted value of 27,443 Da for subtilisin Carlsberg containing an added phenylmethylsulfonyl group. For comparison the predicted molecular weight for subtilisin BPN` is 246 mass units higher - 27,689 Da. Literature ESI measurements of non-inhibited subtilisin gave molecular weights of Carlsberg: $27289 \mathrm{Da}$, and BPN`: $27536 \mathrm{Da}^{4}{ }^{4}$ The phenylmethylsulfonyl group adds a mass of $155 \mathrm{~g} / \mathrm{mol}$, giving a total molecular weight of Carlsberg: 27443 Da, and BPN`: 27690 Da.

Preparation of Subtilisin BPN`and Subtilisin E. Protease deficient B. subtilis DB $104^{5}$ was transformed with vector $\mathrm{pS} 4,{ }^{6}$ which encodes for subtilisin BPN` and chloramphenicol resistance. Transformed cells were grown in $2 \mathrm{XSG}^{7}$ media $(250 \mathrm{~mL})$ containing chloramphenicol $(12.5 \mu \mathrm{g} / \mathrm{mL})$ with shaking overnight at $37^{\circ} \mathrm{C}$. This culture was used to inoculate $5 \mathrm{~L}$ bioreactor containing the same medium. After 47 hours the culture was cooled and centrifuged at 7000 $\mathrm{rpm} / 4{ }^{\circ} \mathrm{C}$. Ammonium sulfate was added $(473 \mathrm{~g} / \mathrm{L})$ and protein was precipitated by allowing the solutions to stand for $1-2$ hours at $4{ }^{\circ} \mathrm{C}$. The precipitate removed by filtration through Celite (Fisher C211) and then resuspended in buffer (20 mM Hepes-1 mM calcium chloride, pH 7.0) and filtered. Impurities in the filtrate were removed by adsorption unto Cellex-D anion exchange cellulose (at pH 7 sulbtilisin is not adsorbed) and re-filtered. The clarified solution placed in a $3.5 \mathrm{kDa}$ cutoff dialysis membrane and dialyzed twice against buffer (20 mM Hepes-1 mM calcium chloride, $6 \mathrm{~L}$, $\mathrm{pH} 7.0$ ) overnight at $4{ }^{\circ} \mathrm{C}$. The dialyzed protein solution was concentrated 
by passage through an $8 \mathrm{kDa}$ cutoff ultra filtration cartridge and purified on a BioCad purification system using a Poros 20HP2 (10 mm x $100 \mathrm{~mm}$ ) column (Applied Biosystems, Foster City, CA). The sample was loaded and washed with $1.8 \mathrm{M} \mathrm{NH}_{4} \mathrm{SO}_{4}$ in $20 \mathrm{mM}$ HEPES ( $\mathrm{pH} 7.0$ ) and then eluted with a linear gradient of $1.8 \mathrm{M}$ to $0 \mathrm{M} \mathrm{NH}_{4} \mathrm{SO}_{3}$ in $20 \mathrm{mM}$ HEPES (pH 7.0). The activity of enzyme was determined using the synthetic peptide $N$-suc-AAPF- $p \mathrm{NA}^{8}(0.2$ $\mathrm{mM}, \mathrm{pH}=7.2,50 \mathrm{mM}$ BES buffer) and the absorbance monitored at $410 \mathrm{~nm}$ : BPN' $7.9 \mathrm{U} / \mathrm{mg}$. Subtilisin E was prepared in a similar manner: $21 \mathrm{U} / \mathrm{mg} .{ }^{3}$ For comparison, commercial samples of subtilisin Carlsberg, which has a 7-fold higher $\mathrm{k}_{\mathrm{cat}} / \mathrm{K}_{\mathrm{M}}$ value for this substrate, ${ }^{9}$ gave the following activities: Fluka 82518: 374 U/mg; Sigma P8038: 374 U/mg; Sigma P5380: 316 $\mathrm{U} / \mathrm{mg}$. Protein concentrations were determined by absorbance readings at $280 \mathrm{~nm}$ and subtilisin extinction coefficients ${ }^{10}$ or using the Bradford assay. ${ }^{11}$ Both gave similar values.

General procedure for enzymatic reactions and analysis. Enzymatic reactions were preformed under the following conditions: $N, N$-bis(2-hydroxyethyl)-2-aminoethanesulfonic acid (BES) buffer (150 $\mu \mathrm{L}, 50 \mathrm{mM}, \mathrm{pH} 7.2), \mathbf{1}(10 \mu \mathrm{L}, 63 \mathrm{mM}$ in acetonitrile containing biphenyl (54 $\mathrm{mM})$ as an internal standard) and an enzyme solution (50 $\mu \mathrm{L}$ typically 5-6 nmol subtilisin). After $6 \mathrm{~h}$ of stirring at $25^{\circ} \mathrm{C}$, acetonitrile $(1.0 \mathrm{~mL})$ was added to precipitate protein and the reaction mixture was centrifuged. The conversion was determined by reverse phase chromatography of this solution on a Zorbax SB-C18 column $(4.6 \mathrm{~mm} \times 250 \mathrm{~mm}$, Agilent, Palo Alto, CA) with acetonitrile/water as the mobile phase, at $254 \mathrm{~nm}$. A standard of known composition of $p$ toluenesulfinamide/biphenyl was used to determine the moles of sulfinamide product. At 254 $\mathrm{nm}$, equimolar $p$-toluenesulfinamide/biphenyl gave an area ratio of 1: 1.94. For 1: 50/50 $\mathrm{MeCN} / \mathrm{H}_{2} \mathrm{O}$, flow $0.6 \mathrm{~mL} / \mathrm{min}$ for $9 \mathrm{~min}$, then gradient to $80 / 20$ over $0.5 \mathrm{~min} ; p$ toluenesulfinamide: $t_{\mathrm{R}}=5.6 \mathrm{~min} ; \mathbf{1}: t_{\mathrm{R}}=7.1 \mathrm{~min}$; biphenyl: $t_{\mathrm{R}}=15.7 \mathrm{~min}$. For 2: $60 / 40$ $\mathrm{MeCN} / \mathrm{H}_{2} \mathrm{O}$, flow $0.6 \mathrm{~mL} / \mathrm{min}$ for $9 \mathrm{~min}$, then gradient to $80 / 20$ over $0.5 \mathrm{~min} ; p$ toluenesulfinamide $t_{\mathrm{R}}=5.1 \mathrm{~min} ; 2, C=8.9 \mathrm{~min}$; biphenyl $t_{\mathrm{R}}=18.1 \mathrm{~min}$. Dihydrocinnamamide, $t_{\mathrm{R}}$ $=5.0 \mathrm{~min}$. overlaps with $p$-toluenesulfinamide, but the absorbance at $254 \mathrm{~nm}$, bandwidth 50 , is negligible. Eluting with $25 / 75 \mathrm{MeCN} / \mathrm{H}_{2} \mathrm{O}$, flow $0.6 \mathrm{~mL} / \mathrm{min}$ gives $p$-toluenesulfinamide $t_{\mathrm{R}}=$ $13.1 \mathrm{~min}$ and dihydrocinnamamide, $t_{\mathrm{R}}=13.4 \mathrm{~min}$. Only subtilisin Carlsberg shows dihydrocinnamamide product; none was detected for subtilisin BPN`. For 3: $45 / 55 \mathrm{MeCN} / \mathrm{H}_{2} \mathrm{O}$, flow 0.6 $\mathrm{mL} / \mathrm{min}$ for $9 \mathrm{~min}$, then gradient to $80 / 20$ over $0.5 \mathrm{~min}$; $p$-toluenesulfinamide: $t_{\mathrm{R}}=5.8 \mathrm{~min} ; 3: t_{\mathrm{R}}$ 
$=6.3 \mathrm{~min}$; biphenyl: $t_{\mathrm{R}}=20.4 \mathrm{~min}$. For $4: 65 / 35 \mathrm{MeCN} / \mathrm{H}_{2} \mathrm{O}$, flow: $0.6 \mathrm{~mL} / \mathrm{min}$ for $9 \mathrm{~min}$, then gradient to $80 / 20$ over $0.5 \mathrm{~min}$; $p$-toluenesulfinamide and $p$-toluamide: $t_{\mathrm{R}}=4.6 \mathrm{~min}$ for both; 4 : $t_{\mathrm{R}}=7.4 \mathrm{~min}$; biphenyl: $t_{\mathrm{R}}=15.8 \mathrm{~min}$. To separate $p$-toluenesulfinamide and $p$-toluamide: $25 / 75$ $\mathrm{MeCN} / \mathrm{H}_{2} \mathrm{O}$, flow: $0.65 \mathrm{~mL} / \mathrm{min}$; $p$-toluamide: $t_{\mathrm{R}}=11.0 \mathrm{~min}$; $p$-toluenesulfinamide: $t_{\mathrm{R}}=11.9$. There was no $p$-toluenesulfinamide detected for reaction with subtilsisin Carlsberg. To determine the enantiomeric excess the reaction was extracted with EtOAc $(3 \times 0.75 \mathrm{~mL})$, dried with $\mathrm{MgSO}_{4}$ and evaporated and analyzed using a chiral stationary phase: Chiralpak AD-H or Chiralcel OD columns (4.6 mm $\times 25 \mathrm{~cm}$, Chiral Technologies, West Chester, PA) at $230 \mathrm{~nm}$. An achiral Discovery Cyano column $(4.6 \mathrm{~mm} \times 25 \mathrm{~cm}$, Supelco, Bellefonte, PA) was placed before the chiral column in cases where the sulfinamide and $N$-acyl sulfinamide enantiomers overlapped. For 1: 80/20 Hexanes/EtOH, flow $0.75 \mathrm{ml} / \mathrm{min}$, Cyano column and Chiralpak AD-H. $p$ toluenesulfinamide, $(S) t_{\mathrm{R}}=20.5 \mathrm{~min},(R) t_{\mathrm{R}}=16.5 \mathrm{~min} ; \mathbf{1}:(R) t_{\mathrm{R}}=22.0 \mathrm{~min},(S) t_{\mathrm{R}}=29.4 \mathrm{~min}$. For 2: 90/10 Hexanes/EtOH, flow $1.0 \mathrm{~mL} / \mathrm{min}$, Chiralpak AD-H. $p$-toluenesulfinamide, $(S) t_{\mathrm{R}}=$ $13.0 \mathrm{~min},(R) t_{\mathrm{R}}=19.2 \mathrm{~min} ; 2:(R) t_{\mathrm{R}}=15.1 \mathrm{~min},(S) t_{\mathrm{R}}=30.3 \mathrm{~min}$; dihydrocinnamamide, $t_{\mathrm{R}}=$ $10.9 \mathrm{~min}$. For 3: 85/15 Hexanes/EtOH, flow $0.75 \mathrm{~mL} / \mathrm{min}$, Cyano column and Chiralcel OD. $p$ toluenesulfinamide, $(R) t_{\mathrm{R}}=17.0 \mathrm{~min},(S) t_{\mathrm{R}}=18.9 \mathrm{~min} ; \mathbf{3}:(R) t_{\mathrm{R}}=21.3 \mathrm{~min},(S) t_{\mathrm{R}}=23.9 \mathrm{~min}$. For 4: 85/15 Hexanes/EtOH, flow $0.75 \mathrm{~mL} / \mathrm{min}$, Cyano column and Chiralpak AD-H. $p$ toluenesulfinamide, $(S) t_{\mathrm{R}}=18.5 \mathrm{~min},(R) t_{\mathrm{R}}=23.4 \mathrm{~min} ; 4:(S) t_{\mathrm{R}}=27.5 \mathrm{~min},(R) t_{\mathrm{R}}=36.4 \mathrm{~min}$; $p$-toluamide: $t_{\mathrm{R}}=18.1 \mathrm{~min}$. The $p$-toluamide overlaps with $(R)$-p-toluenesulfinamide on this chiral column, but there is none present as determined by reversed phase HPLC. The $E$ value was determined from the conversion and enantiomeric excess according to:

$E=\frac{\ln \left[1-c\left(1+e e_{P}\right)\right]}{\ln \left[1-c\left(1-e e_{P}\right)\right]}$ or $E=\frac{\ln \left[1-c\left(1-e e_{S}\right)\right]}{\ln \left[1-c\left(1+e e_{S}\right)\right]}$

where $\mathrm{E}$ is the enantioselectivity, $\mathrm{c}$ is the conversion, $\mathrm{ee}_{\mathrm{p}}=$ enantiomeric excess of product and $\mathrm{ee}_{\mathrm{s}}=$ enantiomeric excess of remaining starting material. ${ }^{12}$ The enantioselectivity for the C-N cleavage was calculated from the enantiomeric purity of the product $p$-toluenesulfinamide and the conversion that corresponds to the $\mathrm{C}-\mathrm{N}$ cleavage reaction. The enantioselectivity for the S-N cleavage was calculated from the enantiomeric purity of the remaining starting material, which was corrected for the amount of each enantiomer that reacted to yields $p$-toluenesulfinamide, and from the conversion that corresponds to the S-N cleavage reaction. Both enantiomeric purities were corrected for the small amount of spontaneous hydrolysis. This calculation is an approxi- 
mation because both enantioselective steps act simultaneously upon the starting material. The $\mathrm{E}$ value is a lower limit of the theoretical value if one path could be suppressed.

Inhibition of reaction with PMSF. Reactions of 1 carried out under the above conditions using enzyme treated with PMSF (phenylmethane sulfinyl fluoride $\left.{ }^{13}\right),(5 \mu \mathrm{L}, 120 \mathrm{mM}$ in MeCN) gave reactions identical to those with no enzyme added.

NMR reaction. NMR was used to determine the products of the subtilisin Carlsberg reaction. Reactions conditions were as follows: $\mathrm{D}_{2} \mathrm{O}(1 \mathrm{~mL})$ containing phosphate buffer $(20 \mathrm{mM}, \mathrm{pD} 7.4$, $\mathrm{pH}+0.4)$ and subtilisin Carlsberg (7.6 mg, Fluka 82518), $d_{3}-\mathrm{MeCN}(100 \mu \mathrm{L}),( \pm)-\mathbf{1}(160 \mathrm{mM})$ and sodium 4,4-dimethyl-4-silapentane-1-sulfonate, ${ }^{14}$ (DSS, $\left.1 \mathrm{mM}\right)$. The reaction was monitored over the course of $6 \mathrm{~h}$ using a $500 \mathrm{MHz}$ instrument. Under these conditions the $\alpha-\mathrm{CH}_{2} \mathrm{Cl}$ group has the following $500 \mathrm{MHz}{ }^{1} \mathrm{H}$ resonances relative to DSS: Chloroacetic acid $\delta=4.033$, chloroacetamide $\delta=4.137$ and $1 \delta=4.110$. The major product was chloroacetamide (relative area $=1$ ), while a small amount of chloroacetic acid (relative area $=0.37$ ) was detected. A blank reaction with no enzyme showed no detectable change over $6 \mathrm{~h}$. Over the course of the reaction the $\mathrm{pH}$ changes slightly due to the acid produced. This causes a slight shift in the $\alpha-\mathrm{CH}_{2} \mathrm{Cl}$ group of 1 as seen in Figure 1b. For the enzymatic reaction at $1 \mathrm{~h}, \delta=4.117 .3 .5 \mathrm{~h} \delta=4.121$ and at $6 \mathrm{~h}$ $\delta=4.124$. The chemical shift of the $\alpha-\mathrm{CH}_{2} \mathrm{Cl}$ group of $\mathbf{1}$ as a function of $\mathrm{pH}$ is shown in Figure S-1 showing that the change in chemical shift in Figure $1 \mathrm{~b}$ is entirely due to the decrease in $\mathrm{pH}$.

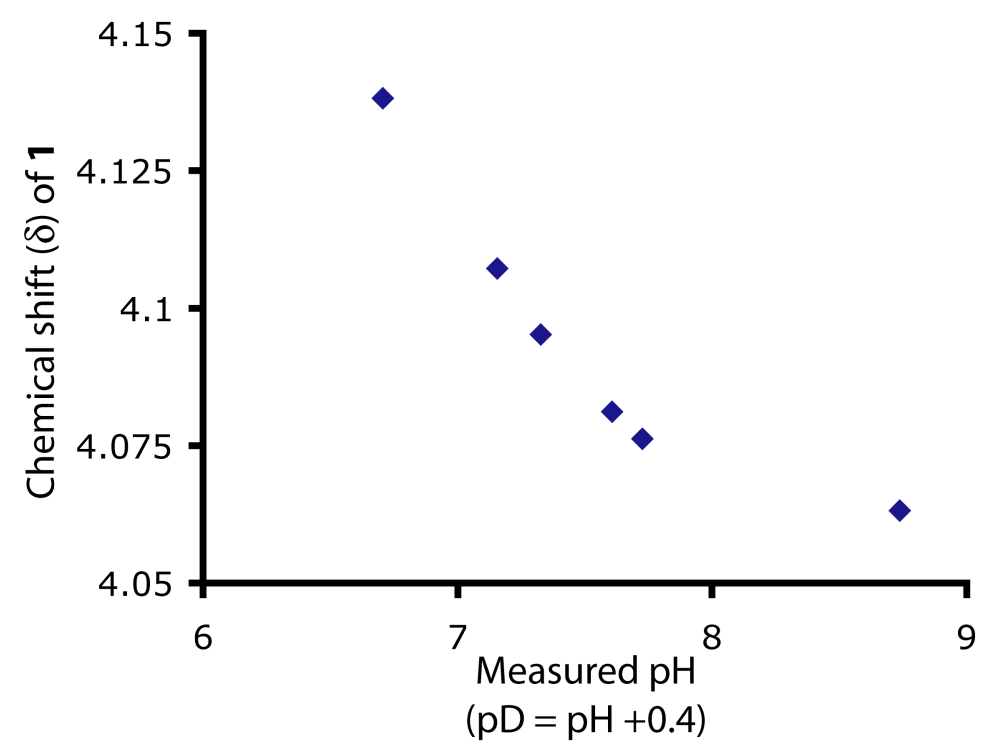


Figure S-1: Effect of $\mathrm{pH}$ on the chemical shift on the methylene of 1 in $\mathrm{D}_{2} \mathrm{O}$.

Isolation of $\boldsymbol{p}$-toluenesulfinic acid. Compound $\mathbf{1}(10 \mathrm{mg}$ in $0.7 \mathrm{~mL} \mathrm{MeCN}, 0.45 \mathrm{mmol})$ in $\mathrm{BES}$ buffer (9.3 mL, $20 \mathrm{mM}$, pH 7.2) was stirred with subtilisin Carlsberg. After $6 \mathrm{~h}$ the reaction was extracted with methylene chloride followed by acidification of the buffer layer with $\mathrm{HCl}(0.1 \mathrm{~N})$. The aqueous layer was extracted with ether $(2 \times 15 \mathrm{~mL})$, dried over $\mathrm{MgSO}_{4}$ and concentrated to yield a white powder $(2.1 \mathrm{mg}, 60 \%)$. TLC $\left(90 / 10 \mathrm{CHCl}_{3} / \mathrm{HCOOH}\right): \mathrm{R}_{\mathrm{f}}=0.3 ;{ }^{1} \mathrm{H} \mathrm{NMR}(400$ MHz): $\delta 2.45(\mathrm{~s}, 3 \mathrm{~Hz}), \delta 7.4(\mathrm{~d}, J=8.2 \mathrm{~Hz}), \delta 7.6(\mathrm{~d}, J=8.2 \mathrm{~Hz})$; HRMS-EI $(\mathrm{m} / \mathrm{z}): \mathrm{M}+$ calcd for $\mathrm{C}_{7} \mathrm{H}_{8} \mathrm{O}_{2} \mathrm{~S}: 156.02450$, found 156.02450 .

Kinetics and inhibition. The inhibition constant $\left(\mathrm{K}_{\mathrm{i}}\right)$ for the hydrolysis of the synthetic peptide $N$-suc-AAPF-pNA ${ }^{8}$ was measured for subtilisins Carlsberg, E, and BPN`. ${ }^{15}$ The inhibition constant for the hydrolysis of the peptide $N$-suc-AAPF-pNA by 1 was measured in a 96 well plate. In each well was placed enzyme solution $(10 \mu \mathrm{L})$ and assay solution containing the peptide and $\mathbf{1}$ $(90 \mu \mathrm{L})$. The assay solution consisted of buffer $(81 \mathrm{~mL}, 50 \mathrm{mM}$ BES, pH 7.2), acetonitrile (8.2 $\mu \mathrm{L})$, and DMSO $(0.8 \mu \mathrm{L})$. The concentration of the peptide was varied from $0.1 \mathrm{mM}$ to $1.6 \mathrm{mM}$, from a $200 \mathrm{mM}$ stock in DMSO. The inhibitor, $\mathbf{1}$, was varied from $0 \mathrm{mM}$ to $7.2 \mathrm{mM}$ (the solubility limit). Each measurement was preformed in triplicate following the release of $p$ nitroanaline at $410 \mathrm{~nm}\left(\varepsilon=8800 \mathrm{M}^{-1} \mathrm{~cm}^{-1}\right)$ over the first $0-35 \mathrm{~s}$. Non-linear curve fitting was preformed on the rate vs. [S] plots using the OriginPro 7.5 software (OriginLab Corporation, Northampton, MA) to determine $\mathrm{V}_{\max }$ and $\mathrm{K}_{\mathrm{m}}$ (inset of Figures $\mathrm{S}-2-\mathrm{S}-4$ ). A replot of inhibitor $\mathrm{V}_{\max } / \mathrm{K}_{\mathrm{m}}$ gave the $\mathrm{K}_{\mathrm{I}}$ values according to the equation:

$$
\text { slope }_{(1 / s)}=\frac{K_{\text {mapp }}}{V_{\text {max }}}=\frac{K_{m}}{V_{\max } K_{I}}[I]+\frac{K_{m}}{V_{\text {max }}}
$$

Where $\mathrm{K}_{\text {mapp }}$ is the apparent $\mathrm{K}_{\mathrm{m}}$ and slope $(1 / \mathrm{s})$ is the slope of the reciprocal Lineweaver-Burk plot $(1 / v$ vs. $1 /[\mathrm{S}])$ for each inhibitor concentration. This plot gives the $\mathrm{x}$-intercept as $-\mathrm{K}_{\mathrm{i} .}{ }^{16}$ 


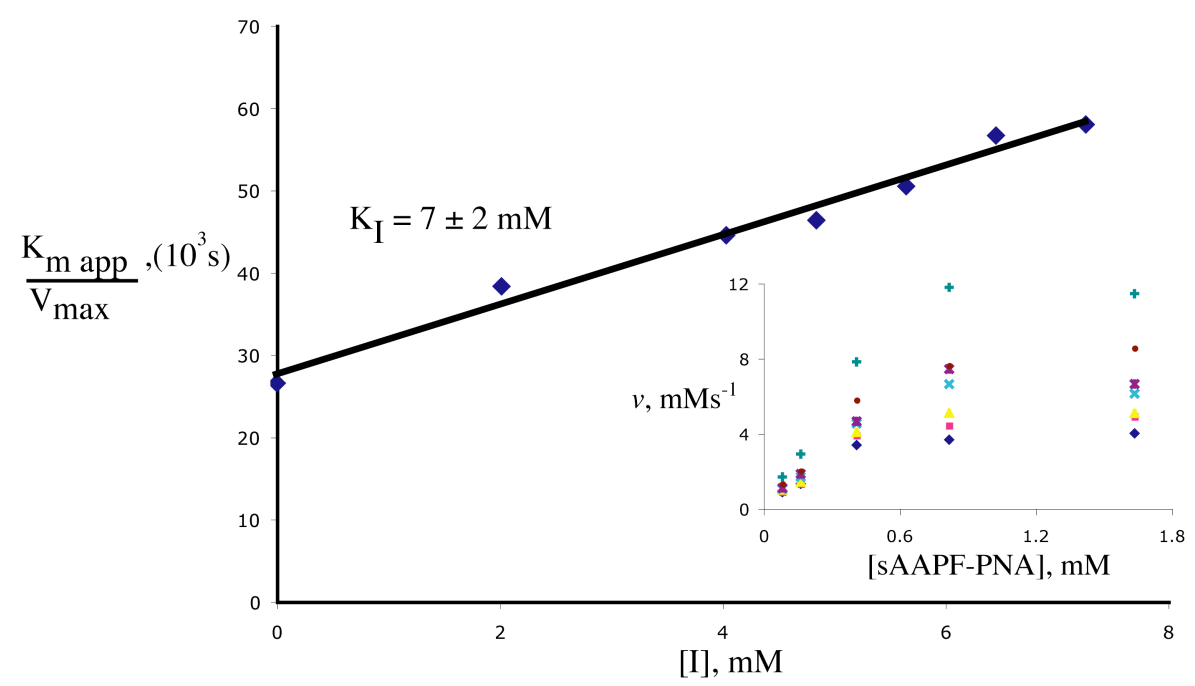

Figure S-2: Replot to determine inhibition constant of subtilisin Carlsberg by 1. Inset: rate (v) vs. $N$-suc-AAPF-pNA peptide concentration at varying inhibitor concentrations.

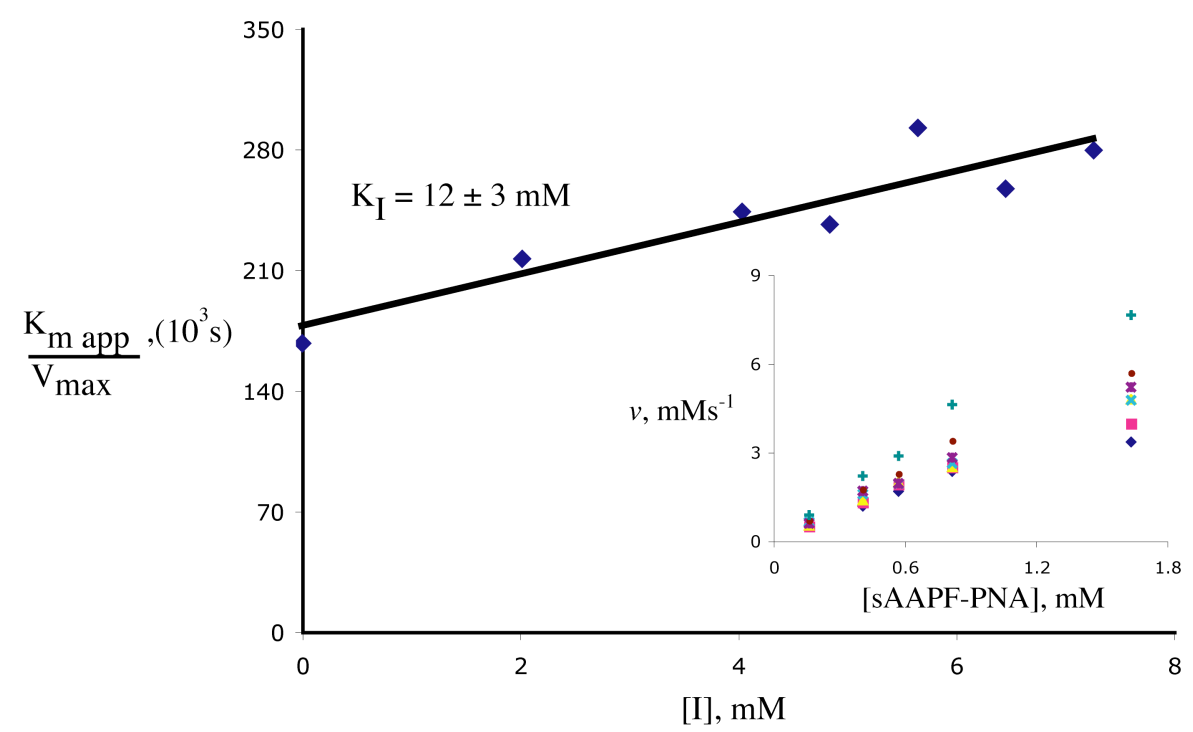

Figure S-3: Replot to determine inhibition constant of subtilisin E by 1. Inset: rate (v) vs. $N$-sucAAPF-pNA peptide concentration at varying inhibitor concentrations. 


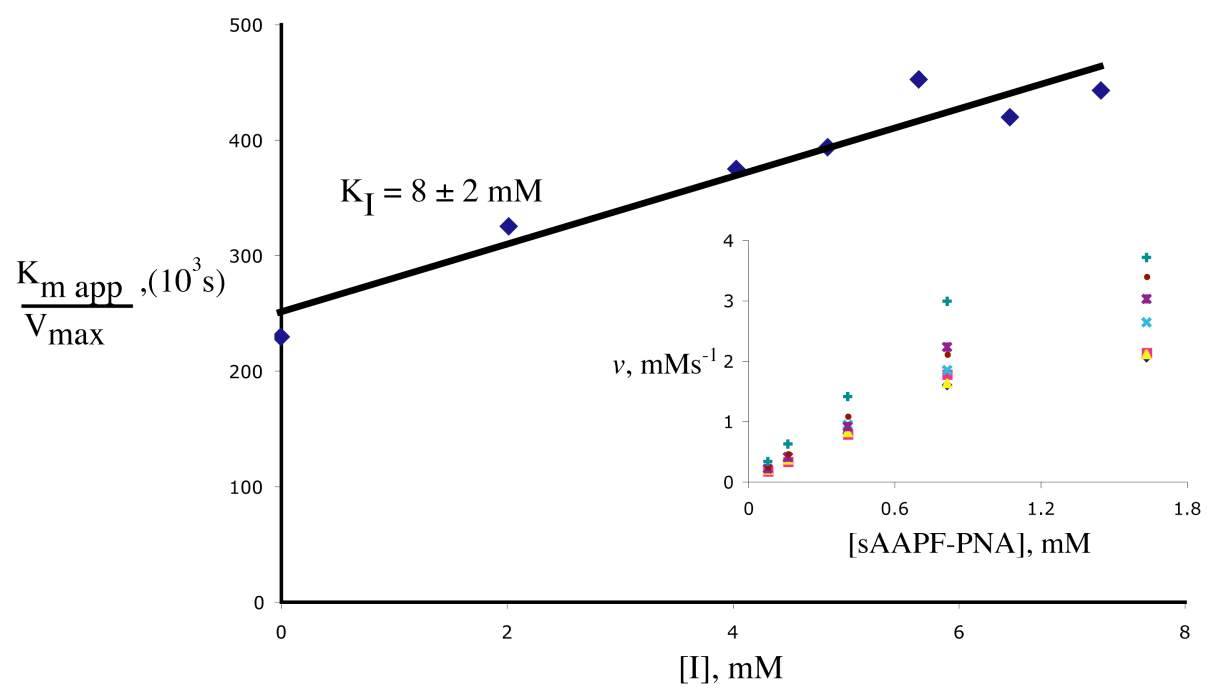

Figure S-4: Replot to determine inhibition constant of subtilisin BPN` by 1 . Inset: rate (v) vs. $N$ suc-AAPF-pNA peptide concentration at varying inhibitor concentrations.

\section{References.}

1.Backes, B. J.; Dragoli, D. R.; Ellman, J. A. J. Org. Chem. 1999, 64, 5472-5478.

2. Chen, F. M. F.; Kuroda, K.; Benoiton, N. L. Synthesis 1978, 928-929.

3. Savile, C. K.; Magloire, V., P.; Kazlauskas, R. J. J. Am Chem. Soc. 2005, in press.

4. Ashton, D. S.; Beddel, C. R.; Cooper, D. J.; Green, B. N.; Oliver, R. W. O.; Welham, K. J. FEBS Lett. 1992, 292, 201-204.

5. Kawamura, F.; Doi, R. H. J. Bacteriol. 1984, 160, 442-444.

6. Wells, J. A.; Ferrari, E.; Henner, D. J.; Estell, D. A.; Chen, E. Y. Nuc. Acids Res. 1983, 11, 7911-7925.

7. Harwood, C. R.; Cutting, S. M. Molecular Biological Methods for Bacillus, John Wiley \& Sons, England, 1990, pp 33-35, 391-402.

8. DelMar, E. G.; Largman, C.; Brodrick, J. W.; Geokas, M. C. Anal. Biochem. 1979, 99, 316320.

9. Wells, J. A.; Cunningham, B. C.; Graycar, T. P.; Estell, D. A. Proc. Nat. Acad. Sci. 1987, 84, 5167-5171.

10. Gill, S. C.; von Hippel, P. H. Anal. Biochem. 1989, 182, 319-326.

11. Bradford, M. M. Anal. Biochem. 1976, 72, 248-254.

12. Chen, C.-S.; Fujimoto, Y.; Girdaukas, G.; Sih, C. J. J Am. Chem. Soc. 1982, 104, 7294-7299. 
13. (a) Farney, D. M.; Gold, A. M. J. Am. Chem. Soc. 1963, 85, 997-1009. (b) James, G.T. Anal. Biochem. 1978. 86, 574-579.

14. Tiers, G. V. D.; Coon, R. I.; J. Org. Chem. 1961, 26, 2097-2098.

15. Bonneau, P. R.; Graycar, T. P.; Estell, D. A.; Jones, J. B. J. Am Chem. Soc. 1991, 113, 10261030.

16. Segel, I. H. Enzyme Kinetics; Wiley \& Sons: New York, 1975, pp 100-124. 